\title{
PREZENTACJE
}

\section{Społeczno-edukacyjna działalność sióstr Marii, Lucyny i Zofii Sokolnickich}

Dzieje Polski, to historia upadków i niewoli, ale również chwały i wolności. W historię tę wpisane sa losy całego narodu oraz losy poszczególnych ludzi, którzy swym życiem, swą działalnościa, walczyli, przegrywając i zwyciężając dla ojczyzny. Często sa to osoby zapomniane, a których życie warte jest naszej pamięci.

Takimi postaciami są siostry Maria, Lucyna i Zofia Sokolnickie - osoby, które poprzez swój ogromny patriotyzm $w$ pracy i słuźbie, dały nieoceniony wręcz dowód swojej głębokiej miłości do Ojczyzny.

Rodzinę Sokolnickich dostrzega się już od czasów Kazimierza Wielkiego i aż do wskrzeszenia Polski rodzina ta brała żywy udzial niemal we wszystkich polskich zrywach zbrojnych i powstaniach.

Siostry Maria, Lucyna i Zofia były krewnymi dwóch generalów napoleońskich - Tadeusza Suchorzewskiego oraz Michała Sokolnickiego (uczestnika bitew pod Raszynem i Lipskiem, teoretyka wojskowości, adiutanta Napoleona Bonaparte) ${ }^{1}$.

Rodzice sióstr, Stanislaw (ur. w 1843 r w Pigłowicach - wsi należącej do Sokolnickich, polożonej niedaleko Środy Wielkopolskiej i zm. w 1906 r.) i Stanislawa (1850 - 1919) z Moszczeńskich, byli właścicielami Orzeszkowa w ówczesnym powiecie średzkim.

W roku 1872 rodzice sióstr Sokolnickich osiedlili się w Poznaniu i tam przyszły na świat Maria, urodzona w 1873 r. i Lucyna urodzona w 1874 r. Zofia urodziła się w Krakowie cztery lata później, 15 maja 1878 roku². $^{2}$.

Pierwsze lata wychowania i kształcenia odbywały siostry Sokolnickie pod troskliwa opieka swych rodziców, których dom ksztattował w nich tradycje patriotyczne i rodzinne. Następnie młode dziewczęta kolejno oddane zostały do Wyższej Szkoły Żeńskiej prowadzonej przez siostry Annę i Anastazję Danyszówny ${ }^{3}$. Szkoła ta była jedną $z$ trzech istniejacych wówczas w Poznaniu żeńskich zakładów naukowych: Antoniny Estkowskiej, sióstr Danysz oraz Anastazji Warnke ${ }^{4}$.

Istnieje duże prawdopodobieństwo, że siostry Sokolnickie ukończyły też dwuletnią szkołę dla nauczycielek, która prowadzily siostry Danyszówny ${ }^{5}$. Nie ma na ten temat dokumentów, ale kiedy w roku 1900 rząd pruski zniósł w całym Zakladzie naukę języka polskiego, lekcji tych zaczęto udzielać w tajnych kólkach w szkole i poza nia, a wśród nauczycielek uczących występuje Lucyna Sokolnicka ${ }^{6}$. Również na fotografii klasowej z 1903 roku wśród uczennic znajduje się nauczycielka - opiekunka - młoda Lucyna Sokolnicka. Poza tym w składzie kolegium nauczającego w szkole PP. Danysz w roku 1909, a więc w momencie, kiedy silna fala germanizacji zamknęła podwoje placówki, figuruje Lucyna oraz jej starsza siostra Maria Sokolnic$\mathrm{ka}^{7}$.

Najmłodsza z sióstr - Zofia Sokolnicka, została wysłana do Krakowa, gdzie na Uniwersytecie Jagiellońskim ukończyła kursy naukowe oraz studia muzyczne w Wyższej Szkole Muzycznej ${ }^{8}$. Po zakończeniu swej edukacji wróciła do Poznania, gdzie zajęła się pracą społeczna i oświatowa.

Wszystkie trzy siostry, przepojone duchem miłości do ojczyzny zaszczepionej im zarówno w domu rodzinnym, jak i w szkole PP. Danysz ${ }^{9}$, działały na polu pedagogicznym, społeczno-kulturalnym i politycznym $w$ okresie tak trudnym dla państwa polskiego.

Szczególnie widoczne (udokumentowane) sa w tej kwestii zasługi Zofii, która rozpoczęła swą 
działalność w sekcji pedagogicznej „Warty" - Towarzystwie Przyjaciół Wzajemnego Pouczania się oraz Opieki nad Dziećmi, które powolano w Poznaniu w 1894 roku. Zadaniem jego było prowadzenie tajnego nauczania języka polskiego i historii, rozprowadzanie polskich książek, ale również organizowanie imprez gwiazdkowych, zabaw dla dzieci, wycieczek, pogadanek dla matek. Nauka odbywała się w mieszkaniach prywatnych, w tajnych kompletach 5-10-osobowych ${ }^{10}$.

Jeden z takich punktów mieścił się właśnie w mieszkaniu sióstr Sokolnickich przy zbiegu ulic Ogrodowej i Piekar. Pod pretekstem nauki haftu i szycia u Pań Sokolnickich zbierały się uczennice, które pobierały naukę historii i języka polskiego. Dzieci otrzymywały zeszyty i książki. Nauka trwała 2-3 lata i kończyly ja egzaminy ${ }^{11}$.

Siostry Sokolnickie miały ułatwione zadanie, ponieważ po zamknięciu szkoły sióstr Danysz, w roku 1909 przejęły placówkę, przekształcając ja w Zakład Wychowawczy dla Dziewcząt.

Zakład Panien Sokolnickich mieścił się przy ulicy Ogrodowej 13 i stał się ośrodkiem polskości, ogniskiem życia religijno-narodowego, punktem centralnym różnych szlachetnych poczynań, miejscem zakonspirowanym, nieustannie kontrolowanym przez zaborcę ${ }^{12}$.

Pensja Pań Sokolnickich miała wyraźny charakter zakładu naukowego, który posiadał własne nauczycielki języka polskiego oraz doskonale opracowany program nauki polskiego na poziomie szkoły wyższej. Do Zakładu uczęszczały dziewczęta $z$ różnych stron: z Poznańskiego, z Pomorza, ze Śląska, a także z wychodźctwa ${ }^{13}$.

Placówkę tę oraz jej twórczynie - siostry Sokolnickie, opisywał w swoich wspomnieniach Witold Sokolnicki - krewny sióstr ${ }^{14}$, który, jak wynika z jego zapisków, jako uczeń Gimnazjum Fryderyka Wilhelma w Poznaniu przy ul. Strzeleckjej, mieszkał prawdopodobnie w okresie swej nauki szkolnej w domu Sokolnickich:

„Osoby, które odegrały b. duża rolę jako moje opiekunki moralne, a następnie były moja podpora moralna i finansowa, gdy zaczałem stawiać samodzielne kroki Osobami tymi były: Maria, Lucyna i Zofia Sokolnickie, córki Stanisława i Stanisławy z Moszczeńskich - wszystkie trzy panny, za mąż nie wyszły (...). Jak sięgam pamięcia, mieszkały zawsze razem $\mathrm{z}$ matka. Ojca nie znalem, umarł w 1906 r. Ludka prowadziła pensjonat dla panienek, Maria i Zofia jej pomagaly".

„Trzeba sobie zdać sprawę, że stosunki, jakie wówczas istniały, ucisk narodowościowy ogromny, tylko i wyłącznie szkoły niemieckie, w których nie wolno było nawet mówić po polsku między kolegami, natomiast $w$ pensjonacie Ludki atmosfera narodowa, tajne nauczanie historii $\mathrm{i}$ jezyka polskiego, polskie śpiewy, najwyższe tradycje napoleońskie i powstań narodowych, gdzie w roku 1863/64 szereg Sokolnickich brało udzial, a między nimi i Stanisław ojciec trzech panien, mój pradziad i inni, którzy za rok 1948 odpokutowali".

„W domu Ludki uczyliśmy się polskiego i historii z coraz większym zapałem, bo wszyscy czuli i głęboko wierzyli, że kończy się okres 130-letniej niewoli, ale nikt sobie jasno sprawy nie zdawał, jak ta Polska wyglądać będzie (...)".

„Pensjonat Ludki (...) mieścił się w dużym 12 pokojowym mieszkaniu (...). Panienki pochodziły z różnych sfer społecznych, najwięcej było ziemianek, ale byly też panny ze sfer kupieckich i mieszczańskich, pochodziły one z całego zaboru pruskiego, z Pomorza, Poznańskiego i Ślaska. Rano panienki szły do szkół, jak wyżej powiedziałem były to szkoły niemieckie, obiad o 2:30 a potem spacer (...). Od godziny 4 była nauka w uczelni do godziny 7, potem kolacja. Po kolacji odbywala się nauka historii i języka polskiego, co było już domeną Ludki, Zosi i Marii, a w sobotę spiewano pieśni narodowe przeważnie te popowstaniowe, gdyż tymi nastrojami wówczas żyto, pamiętajmy, ze bylo to jeszcze przed pierwsza wojną swiatowa (...).

Niezależnie od pracy pedagogicznej Zosia zajmowala się czynnie polityka, należała do $\mathrm{Na}$ rodowej Demokracji, to też miała czesste kontakty z Dmowskim, który często bywał w saloniku czerwonym przy ul. Ogrodowej"15.

Obok wspólnego trudu pedagogicznego sióstr Sokolnickich, jakim był wzorowy Zakład dla Dzjewczat, na uwage zasługuje też polityczno-konspiracyjna działalność sióstr. Szczególnie Zofia zapisala się na kartach historii ogromnym oddaniem dla Polski. Była ona współzałożycielka wielu organizacji, jak Straż Polska, gdzie pracowała w Sekcji Kulturalnej, Towarzystwo Śpiewacze „Lutnia”, Spółka dla Popierania Przemysłu Domowego „Znicz”, Towarzystwo Gimnastyczne 
„Sokót”, Towarzystwo Pedagogiczne, Zjednoczenie Polskich Kobiecych Towarzystw Oświatowych, którego celem było szerzenie oświaty wśród kobiet oraz przygotowanie członkiń do różnego rodzaju pracy społecznej, Towarzystwo Czytelni Ludowych i Czytelni dla Kobiet ${ }^{16}$.

W roku $1913 \mathrm{Z}$. Sokolnicka przyczyniła się do powołania Towarzystwa Wykładów Naukowych, które organizowało wyklady polskich naukowców ze Lwowa i Krakowa w Poznaniu, Gnieźnie i Inowrocławiu. Organizowała ona na terenie Wielkopolski tajne koła Zwiazku Mlodzieży Polskiej „Zet” oraz Towarzystwa Tomasza Zana, skupiając na spotkaniach młodzież akademicką i gimnazjalna ${ }^{17}$.

Siostry Sokolnickie przez wiele lat prowadzily u siebie $w$ domu tajna księgamię TTZ, starając się zaopatrzyć ja jak najlepiej w książkj oraz zachować jej tajność ${ }^{18}$.

We wrześniu 1915 roku w Lozannie odbyło się zebranie kilkudziesięciu Polaków, na którym Erazm Piltz przedłożył projekt założenia centralnej Agencji Polskiej, kıórej celem miało być „informowanie prasy europejskiej o sprawie polskiej i rozwoju bieżących wypadków w kraju"19. Już wówczas zaczałł wylaniać się w Agencji program odbudowy niepodległości państwa polskiego. Jednak, aby Agencja mogła funkcjonować, potrzebowała stałej łączności z krajem. I tutaj do pracy włączyła się Zofia Sokolnicka, podejmujac się roli pośrednika pomiędzy Lozanna, później też Paryżem, a zaborem pruskim. Moment ten wspomina również Witold Sokolnicki, pisząc:

„W tym czasie Zosia była bardzo czynna politycznie, jak już wspomniałem pracowala ona już przed wojna $z$ Dmowskim, na terenie Poznania; najbliższymi współpracownikami byli dr Krysiewicz i p. Seyda. Chodziło o to, aby przekazywać bezpośrednio wiadomości Paderewskiemu i Dmowskiemu do Francji. Zosia chorowała ciężko na oczy i grozila jej utrata wzroku, na tej podstawie otrzymała trzykrotnie od władz niemieckich zezwolenie na udanie się do Szwajcarii na leczenie kliniczne, które tam stało na b. wysokim poziomie. Zosia kontaktowała się na terenie Szwajcarii z emisariuszami" 20 .

Pod pozorem swej choroby wywoziła Zofia Sokolnicka z ojczyzny i przywozila do niej skarby wiary i podniesienie na duchu, ucząc się na pamięć wszystkich poleceń i instrukcji tak, aby wróg, który podejrzewał, nigdy nie mógł jej przyłapać. Zarówno Zofia, jak i cała rodzina Sokolnickich znajdowała się pod ścisłym nadzorem policyjnym.

Najciekawszymi były listy Zofii Sokolnickiej zza granicy, adresowane rzekomo do rodziny, a w rzeczywistości zawierające zaszyfrowane wiadomości do Komitetu Międzypartyjnego. W listach tych Sokolnicka pod postacia przepięknych opisów górskich krajobrazów, pod forma opisów wschodu i zachodu słońca, zdawała szczegółowe relacje $z$ narad odbywających się w Szwajcarii, prosząc o wiadomości i wskazówki.

W konspiracyjne przekazywanie wiadomości zaangażowana była cała rodzina Sokolnickich piszac i tworzac coraz to nowe szyfry tak, aby uprzedzić wroga. Kolejne listy, kartki, w których mowa była o pozornie nic nie znaczacych sprawach, w których np. matka Zofii Sokolnickiej, Stanisława pisze list do córki, w którym donosi jej o zdrowiu służacej, o nowinach rodzinnych, o postępach $w$ nauce Witolda Sokolnickiego (mały chłopczyk nie wie nic o tym, że imię jego jest synonimem wieści politycznych) ${ }^{21}$.

Pomimo wielu przeszkód $\mathrm{w}$ działalności, Zofia Sokolnicka nie przerywała swej pracy w charakterze lącznika aż do 1919 roku, a siostry i matka sumiennie pomagały jej $w$ jakże wspaniatej misji.

W połowie 1918 roku powstala Tajna Komisja Szkolna dla spolszczenia szkolnictwa, której inicjatorka i bezpośrednia założycielka byla Zofia Sokolnicka, opracowując przy współpracy innych osób plan przyszłych szkół polskich ${ }^{22}$.

Gdy w 1919 roku po szczęśliwym przebiegu powstania wielkopolskiego Poznań stał się znowu integralna częścia Rzeczpospolitej Polskiej, rozpoczęła się natychmiast reorganizacja szkolnictwa. Przy Naczelnej Radzie Ludowej ujawniła się tajna dotad od połowy 1918 roku Komisja dla spolszczenia szkoły średniej. Do Komisji tej należały m.in. Lucyna i Zofia Sokolnickie ${ }^{23}$.

W maju 1919 roku zaczęły powstawać szkoły polskie. W chwili tej Lucyna Sokolnicka nabyła razem z Aleksandra Stomińską niemiecko-katolicka wyższa szkołę żeńską p. Linke (dawniejsza Wyższa Szkoła p. Anastazji Warnkówny) przy Placu Świętokrzyskim 4. Dekretem z dnia 10 czerwca 1920 roku liczba 663/20, Komisja dla 
Spraw Wyznaniowych i Szkolnych nadała szkole prawo używania nazwy Liceum Żeńskie im. Królowej Jadwigi z wszelkimi prawami przysługujacymi tego typu szkolom ${ }^{24}$.

Wobec wzrastającej liczby uczennic, właścicielki szkoły zdecydowały $\mathrm{z}$ dniem 1 września 1920 roku przekształcić ja na dwa odrębne zakłady: Liceum im. Królowej Jadwigi, którego właścicielką i kierowniczka została Lucyna Sokolnicka oraz Liceum pod wezwaniem Najświętszego Serca Jezusa, którego właścicielką i kierowniczka została Aleksandra Slowińska. Kuratorium, po przeprowadzeniu wizytacji, przyznało obydwu zakładom pełne prawa publiczności ${ }^{25}$.

W roku szkolnym 1924/25 rozpoczęło się stopniowe przeobrażanie Liceum w Gimnazjum: na mocy rozporzadzenia Ministerstwa Wyznań Religijnych i Oświecenia Publicznego z dnia 15 listopada 1924 roku, Zakład otrzymał nazwę Rozwojowego Gimnazjum Żeńskiego im. Królowej Jadwigi z pełnymi prawami gimnazjów państwowych o programie humanistycznym ${ }^{26}$.

Zofia Sokolnicka współdziałała w tworzeniu Narodowej Organizacji Kobiet. Bylo to pierwsze w dziejach polskiego ruchu kobiecego w Wielkopolsce zrzeszenie stawiające sobie za cel prace polityczna. Hasłem NOK była Polska katolicka i narodowa. Stowarzyszenie podjęło się obrony praw kobiet $w$ życiu rodzinnym, w pracy, w dziedzinie spraw cywilnych, majatkowych i politycznych. Członkinie starały się uświadamiać narodowo masy poprzez kolportaż broszur i gazetek, zamieszczanie artykułów w pismach, wygłaszanie odczytów i pogadanek, organizowanie wieczornic i zabaw. NOK wprowadziła swoje posłanki do Sejmu i Senatu, gdzie były one inicjatorkami szeregu ustaw i projektów ${ }^{27}$.

1 czerwca 1919 roku odbyły się wybory uzupełniajace do Sejmu Ustawodawczego. Do Sejmu z ramienia Stronnictwa Narodowo Demokratycznego z Okręgu III Poznańskiego została wybrana między innymi Zofia Sokolnicka, dla której skończył się okres walki $z$ germanizacja, a rozpoczał czas ciężkiej pracy nad odbudowa państwa i szkolnictwa polskiego. W $1922 \mathrm{r}$. ponownie kandydowała i została posłem na Sejm z okręgu 34, który objał miasto Poznań.

Z. Sokolnicka składala wnioski w sprawach oświatowych. Podczas plenarnych posiedzeń Sejmu referowała kilka ustaw: o pomocy naukowej i materialnej dla młodzieży, o rozwoju szkół wyższych i nauki, o polepszeniu bytu i pracy naukowej profesorów szkół wyższych, o zmianie ustawy o szkolnictwie akademickim, o kwalifikacjach potrzebnych do nauczania w szkołach średnich ${ }^{28}$. W wielu swych przemówieniach poruszała problematykę nurtująca szkolnictwo wielkopolskie. Na posiedzeniu sejmowym 30 listopada 1920 roku upominała się $\mathrm{z}$ Trybuny Parlamentamej o inwestycje dla Uniwersytetu Poznańskiego ${ }^{29}$, Akademii Umiejętności w Krakowie, Towarzystwa Przyjaciół Nauk w Wilnie, Poznaniu i Toruniu, Towarzystwa Nauk Warszawskiego i Lwowskiego, i wielu innych mniejszych, których liczba sięga $100^{30}$.

W przemówieniu tym mówila:

„Nauka jest źródłem twórczej myśli i inicjatywy, podstawą wszelkiej pozytywnej pracy i działalności, stanowi więc nieodzowny warunek stałego i wszechstronnego postępu narodów i państw i jest zarazem jednym $\mathrm{z}$ regulatorów stanowiska ich w ludzkości" ${ }^{31}$.

Zofia Sokolnicka była współtwórczynia 20 ustaw. W latach 1922-1927 przemawiała na plenarnych posiedzeniach 18 razy, zgłosila 26 interpelacji i wniosków.

Wiosną 1927 roku stan jej zdrowia wyraźnie się pogorszył. Bardzo przeżyła zamach majowy Józefa Piłsudskiego. Powołano ją do Komitetu Wojewódzkiego Organizacji Obrony Państwa, który utworzono w Poznaniu, aby przeciwstawić się zamachowi wojskowemu ${ }^{32}$.

Zmarła 27 lutego 1927 r. w Poznaniu, a pogrzeb jej stał się manifestacja patriotyczna, w której brali udział posłowie i senatorzy Drugiej Rzeczypospolitej, władze Wielkopolski oraz wszyscy mieszkańcy Poznania z młodzieżą na czele, która tak dużo zawdzięczała Zmarłej.

Siostry Lucyna i Maria nadal prowadzily Gimnazjum im. Królowej Jadwigi przy ulicy Ogrodowej 13 oraz pensjonat przy ulicy Podgórnej, utrzymując je w duchu głębokiego patriotyzmu, w myśl hasła „Bóg i Ojczyzna" 33 .

We wrześniu 1928r. otwarto czwartą klasę gimnazjum neohumanistycznego $w$ miejsce czwartej klasy licealnej ${ }^{34}$. Szkoła cieszyła się ogromnym uznaniem ówczesnych władz oświatowych, które, doceniając wspaniała pracę dydaktyczna i wychowawcza, podkreślały stałe podnoszenie - przez Dyrekcję Zakładu oraz grono nauczyciels- 
kie - naukowego poziomu Szkoły. Praca ta przyczyniła się do tego, że Ministerstwo W. R. i O. P. corocznie udzielało Gimnazjum praw gimnazjów państwowych $^{35}$.

Była uczennica Gimnazjum, Anna Michalska z domu Korzeniewska, uczęszczała do tej Szkoły w latach 1928-1931, realizujac w niej cztery pierwsze klasy wstępne, a następnie przeszla, ze względu na zmianę miejsca zamieszkania, do Gimnazjum im. Gen. Zamoyskiej w Poznaniu, które kończyła już według reformy jędrzejewiczowskiej. Obecnie 82-letnia Pani Anna Michalska, mieszkanka Milion Keynes w Wielkiej Brytanii, Szkołę „Ludki” Sokolnickiej wspomina bardzo ciepło. Twierdzi, że zawsze panowała tam mila atmosfera, a Pani Dyrektor Lucyna, pomimo swego poważnego wyglądu (chodziła w długiej "staromodnej" sukni oraz spiętych w kok jasnych włosach), była osobą pogodna, życzliwą, szczerze interesujaca się każda swoją wychowanką.

Marię Sokolnicką Anna Michalska pamięta jako osobę, która pomagała swej starszej siostrze w prowadzeniu Gimnazjum, często widywano ja w sekretariacie Szkoły. Poza tym Maria zajmowała się głównie istniejącym przy ulicy Podgórnej internatem dla tych dziewcząt, które mieszkały zbyt daleko od szkoły i w zwiazku z tym były pensjonarkami internatu i jednocześnie podopiecznymi Marii Sokolnickiej.

Anna Michalska Zofii Sokolnickiej nie miała okazji poznać osobiście. Jednak duch jej musiał głęboko tkwić w murach Szkoly, w przekazach, opowieściach na jej temat, ponieważ określiła Zofię jako „Wielką Patriotkę"36.

Druga z bylych uczennic, która uczęszczała do Szkoły Sokolnickiej w latach 1934 -1939, to Stefania Tokarska-Kaszubowa, mieszkająca obecnie w Poznaniu. Chodziła ona do Gimnazjum im. Królowej Jadwigi wraz z dwiema starszymi siostrami - Henryką, uczennica Szkoły Sokolnickiej w latach 1930-1939, która zdała jeszcze tzw. "mała mature" w 1939 r. oraz Izabella, która uczęszczała do Zakładu w latach 1931 - 1939. Z okresu tego zachowały się świadectwa w/w pań oraz Znaczek Szkoly z inicjalami GKJ umieszczonymi wśród laurowych liści, który uczennice nosiły na granatowych beretach ${ }^{37}$.

Pani Stefania Tokarska-Kaszubowa wspomina Zakład jako Szkołę demokratyczna, ale samą Przełożoną - Lucynę Sokolnicką określa jako osobę surową, poważna, utrzymującą dyscyplinę w Gimnazjum. Ze świadectw ${ }^{38}$ sióstr Tokarskich wynika, że Gimnazjum im. Królowej Jadwigi po wprowadzeniu reformy jędrzejewiczowskiej również uzyskiwało prawa gimnazjum państwowego. Nie ma natomiast dokumentów świadczących o tym, że prawa te posiadało we wszystkich latach szkolnych do 1939 r.

Lucyna, Maria i Zofia Sokolnickie - wspaniałe osobowości, ogromne patriotki, oddane nauczycielki, osoby, które swym życiem zasłużyły na miano Wielkich Polek.

Niech poniższy cytat za wspomnieniami Witolda Sokolnickiego, będzie najlepszym podsumowaniem jakże doniosłego znaczenia społeczno-edukacyjnej działalności sióstr Sokolnickich w dziejach narodu polskiego:

„Maria, Lucyna i Zofia Sokolnickie - wszystkie trzy o złotych sercach, gorliwe i ofiame patriotki, wybitne nauczycielki o rzadkim zmyśle pedagogicznym"39.

\section{Bibliografia}

Alfabet Zofii Sokolnickiej, (W:) „Kurier Poznański" 1928.

Dziennik Poznański 1927/Nr 49.

Karczmarek Z., Zofia Sokolnicka (1878-1927), (W:) Wielkopolanie XX wieku, (red.) A. Gulczyński, Poznań 2001.

Kobieta w Sejmie, Warszawa 1928.

„Kronika Miasta Poznania” 1927.

„Kurier Poznański” 1927/Nr 94.

Listy Stanisławy Sokolnickiej i Lucyny Sokolnickiej do Zofii Sokolnickiej, ze zbiorów prywatnych Katarzyny Męczeńskiej.

Mowa Posła Zofii Sokolnickiej wygłoszona na 191 posiedzeniu Sejmu Ustawodawczego dn. 30 listopada 1920 r. podczas sprawozdania Komisji Oświatowej i Skarbowo-Budżetowej o wniosku p. Z. Sokolnickiej i Tow.. z Klubu Związku Ludowo-Narodowego, Warszawa 1920.

Seyda M., Polska na przełomie wieków, t. I, Poznań 1927.

Sokolnicka Z., O pracy tajnej Towarzystwa Tomasza Zana pod jarzmem pruskim, Warszawa 1921.

Sokolnicka Zofia, (W:) Polski Stownik Biograficzny, t. XL, Warszawa 2000-2001. 
Sprawozdanie Dyrekcji Prywainego Gimnazjum Zeńskiego im. „Królowej Jadwigi" Lucyny Sokolnickiej w Poznaniu za lata 1919-1929, Poznań 1930.

Świadectwa szkolne z Prywatnego Gimnazjum im. Królowej Jadwigi, ze zbiorów prywatnych Stefanii Tokarskiej-Kaszubowej.

Towarzystwo Oświatowe „Warta”, Biblioteka Raczyńskich, sygn. 1034.

Towarzystwo Oświatowe „Warta”. Narodowa Organizacja Kobiet. Biblioteka Raczyńskich, sygn. $1060-\mathrm{H}$.

Wspomnienia Witolda Sokolnickiego, maszynopis w posiadaniu rodziny.

I Z. Karczmarek, Zofia Sokolnicka (1878-1927), (W:) Wielkopolanie XX wieku, (red.) Andrzej Gulczyński, Poznań 2001, s. 513.

2 Ibidem, s. 513; Sokolnicka Zofia, (W:) Polski Slownik Biograficzny, t. XL, Warszawa 2000-2001, s. 57.

${ }^{3}$ Zaklad pp. A. A. Danysz istnial pod rozmaita nazwa, ale bez przerwy od 1815 roku. W roku 1815 pani Tekla Herwigowa, babka prof. Marcelego Mottego, otworzyla zakład wychowawczy dla panien, prowadząc go 30 lat, poczatkowo jako pensjonat. Po wypadkach politycznych w 1846 i 1848 roku, Tekla Herwigowa przekształcila zakład na szkolę. W pracy pomagala jej córka, Katarzyna Poplińska, która po śmierci matki prowadziła placówkę. Naczelne kierownictwo objąl wówczas Jan Motty, a po jego śmierci kierownictwo i odpowiedzialność spoczęła na synu - Marcelim Mottym. W roku 1871 Katarzyna Poplińska oddała szkołę swym wychowankom Annie i Anastazji Danysz, Sprawozdanie Dyrekcji Prywatnego Gimnazjum Zeńskiego im. „Królowej Jadwigi" Lucyny Sokolnickiej w Poznaniu za lata 1919-1929, Poznań 1930, s. 6-7.

4 Sprawozdanie Dyrekcji Prywatnego Gimnazjum Zeniskiego im. ..Królowej Jadwigi" Lucyny Sokolnickiej, s. 5; Z. Karczmarek, Zofia Sokolnicka, s. 513; Ze wspomnień rodzinnych, Wywiad z Katarzyna z Sokolnickich Męczeńska, Poznań, 5 listopada 2004.

5 Panie Danysz w roku 1876 otworzyły w swojej szkole tzw. Selektę, czyli rodzaj wyższego seminarium, które w dwuletnim kursie przysposabiało uczennice do składania rzadowego egzaminu na nauczycielki tak zwanych wyższych szkół żeńskich (był to w owych czasach najwyższy typ uczelni dla dziewcząt w zaborze pruskim). $\mathrm{Z}$ seminarium tego prowadzonego wzorowo przez 24 lata swego istnienia wyszedł cały zastęp wybitnych nauczycielek-wychowawczyń, które, oceniane jako pierwszorzędne, sumienne nauczycielki, poszukiwane byly we wszystkich trzech zaborach, Sprawozdanie Dyrekcji Prywatnego Gimnazjum Zeniskiego im. „Królowej Jadwigi" Lucyny Sokolnickiej, s. 8.

${ }^{6}$ Sprawozdanie Dyrekcji Prywatnego Gimnazjum Zeńskiego im. .,Królowej Jadwigi" Lucyny Sokolnickiej, s. 9.
${ }^{7}$ Ibidem, s. 11; Fotografia, na której znajduje się Lucyna Sokolnicka - mloda nauczycielka wraz z klasa - grupa dziewczynek, ze zbiorów prywatnych Katarzyny Sokolnickiej.

8 ,Kurier Poznański” 1927/Nr 94; Sokolnicka Zofia, (W:) Polski Slownik Biograficzny, T. LX, Warszawa $2000-2001$.

qarówno szkola, jak i sama jej przełożona - Anna Danysz, wywierala wielki wplyw na uczennice swym przykładem i niepowszednią indywidualnościa. Wybitna inteligencja laczyla się $w$ niej $z$ serdecznym przywiazaniem do wychowanek, $\mathrm{z}$ wielkodusznym charakterem oraz glębokimi przekonaniami religijnymi. Uważajac szkołe za przygotowanie do dalszego życia, wpajala w młodzież uczucia obywatelskie, uczucia odpowiedzialności przed Bogiem i ludźmi, miłości bliźniego i Ojczyzny, Sprawozdanie Dyrekcji Prywatnego Gimnazjum Zeniskiego im. ,Królowej Jadwigi" Lucyny Sokolnickiej, s. 9 .

10 Towarzystwo Oswiatowe „Warta”, Biblioteka Raczyńskich, sygn. 1034.

11 Z. Karczmarek, Zofia Sokolnicka, s. 514.

12 Sprawozdanie Dyrekcji Prywatnego Gimnazjum Zeniskiego im. "Królowej Jadwigi" Lucyny Sokolnickiej, s. 15,13

13 Ibidem, s. 16

14 Witold byl wnukiem brata dziadka sióstr Sokolnickich ze strony ojca. Dziadek sióstr, to Tadeusz Sokolnicki, ojciec Stanisława Sokolnickiego. Brat dziadka Tadeusza, to Józef, który byl dziadkiem Witolda, z drzewa genealogicznego rodziny Sokolnickich, zbiory rodzinne.

15 Wspomnienia Witolda Sokolnickiego, maszynopis w posiadaniu rodziny.

16 Sokolnicka Zofia, (W:) Polski Stownik Biograficzny, T. LX, Warszawa 2000-2001.

17 „Dziennik Poznański” 1927/Nr 49.

18 Z. Sokolnicka, O pracy tajnej Towarzystwa Tomasza Zana pod jarzmem pruskim, Warszawa 1921, s. 5.

19 M. Seyda, Polska na przetomie wieków, t. I, Poznań 1927, s. 295.

20 Wspomnienia Witolda Sokolnickiego, maszynopis w posiadaniu rodziny.

21 Alfabet Zofii Sokolnickiej, (W:) „Kurier Poznański" 1928; Listy Stanislawy Sokolnickiej i Lucyny Sokolnickiej do Zofii Sokolnickiej, ze zbiorów prywatnych Katarzyny Męczeńskiej.

${ }^{22}$ Sprawozdanie Dyrekcji Prywatnego Gimnazjum Żenskiego im. "Królowej Jadwigi" Lucyny Sokolnickiej, s. 16 ,

23 Ibidem, s. 16.

24 Lucyna Sokolnicka - przełożona Liceum i Gimnazjum im. Królowej Jadwigi, była nauczycielką na pensji sióstr Danysz, a po zamknięciu tej szkoły, przejęła jej internat, posyłając niektóre swoje wychowanki najpierw do Zakładu Anastazji Warnke, a później, do Gertrudy Linke, która przejęła Zakład Warnkówny po nasileniu się procesu germanizacji. W ten sposób poprzez osobę Lucyny Sokolnickiej istnieje bezpośrednie nawiazanie przez pensję Panien Danysz przejęta przez siostry Sokolnickie oraz przez szkołę Anastazji Warn- 
kówny, do Liceum i Gimnazjum im. Królowej Jadwigi, Sprawozdanie Dyrekcji Prywatnego Gimnazjum Żeniskiego im. „Królowej Jadwigi” Lucyny Sokolnickiej, s. 5 .

25 Ibidem, s. 17.

26 Sprawozdanie Dyrekcji Prywatnego Gimnazjum Żeńskiego, s. 18 .

27 Towarzystwo Oświatowe „Warta". Narodowa Organizacja Kobiet. Biblioteka Raczyńskich, syg. $1060-\mathrm{H}$.

${ }^{28}$ Kobieta w Sejmie, Warszawa 1928 r., s. 5.

29 Zofia Sokolnicka zwracała się do Rządu o finanse dla Wydziału Lekarskiego na urzadzenie i uruchomienie zakładów dla medycyny teoretycznej i klinicznej. Zwrócila uwagę, że Uniwersytet kształci kadry dla Wielkopolski, Pomorza i Śląska, a dominuja lekarze pochodzenia niemieckiego lub żydowskiego. Twierdziła, że jeśli z Poznania ma promieniować polska kultura na ziemie graniczace $\mathbf{z}$ odwiecznym wrogiem, należy rozbudowywać polskie placówki naukowe, Wielkopolanie XX wieku, s. 517.

30 Mowa Posła Zofii Sokolnickiej wygłoszona na 191 posiedzeniu Sejmu Ustawodawczego dn. 30 listopada 1920 r. podczas sprawozdania Komisji Oświatowej i Skarbowo-Budżetowej o wniosku p. Z. Sokolnickiej i tow. z Klubu Zwiazku Ludowo-Narodowego, Warszawa 1920, s. 21-22.

31 Ibidem, s. 2.

32 Wielkopolanie $X X$ wieku, s. 520

33 Sprawozdanie Dyrekcji Prywatnego Gimnazjum Żeniskiego, s. 18; Zakrzewski Z., Ulicami mojego Poznania, Poznań 1985, s. 243.
${ }^{34}$ W roku szk. 1929/30 Zakład obejmowal: czteroklasowa szkolę przygotowawcza (według programu Ministerstwa dla szkół powszechnych), pełne 8-klasowe gimnazjum typu humanistycznego, klasy IV i V gimnazjum neohumanistycznego (ze wspólną podbudowa gimnazjum niższego, klasy I, II i III), Sprawozdanie Dyrekcji Prywatnego Gimnazjum Żeńskiego, s. 18.

35 Sprawozdanie Dyrekcji Prywatnego Gimnazjum Żeńskiego, s. 18.

36 Wywiad telefoniczny z Pania Anna Michalska z d. Korzeniewską - była uczennica Gimnazjum im. Królowej Jadwigi, zamieszkalą obecnie w Milion Keynes w Wielkiej Brytanii, przeprowadzony w dniu $08 \quad 11$ 2004 r.

${ }^{37}$ Wywiad z Pania Stefania Tokarska-Kaszubowa - była uczennica Gimnazjum im. Królowej Jadwigi w Poznaniu, przeprowadzony w dniu 25 listopada 2004 r., Świadectwa szkolne oraz Znaczek Szkoly z inicjalami GKJ w zbiorach prywatnych Stefanii Tokarskiej-Kaszubowej; Zakrzewski Z., Ulicami mojego Poznania, s. 86.

38 Na jednym ze świadectw - pani Stefanii Tokarskiej - u góry umieszczona jest pieczęć, która informuje o tym, że Kurator Okręgu Szkolnego Poznańskiego Zarzadzeniem z dnia 24 kwietnia 1933 r. nadał Szkole Lucyny Sokolnickiej prawa szkoły państwowej. Nie ma natomiast informacji, czy pieczęć taka była obowiązkowa na wszystkich swiadectwach i we wszystkich latach funkcjonowania Zakładu. Z relacji pani Stefanii Tokarskiej wynika, że Szkoła posiadała prawa państwowości.

39 Wspomnienia Witolda Sokolnickiego, maszynopis $\mathrm{w}$ posiadaniu rodziny. 